\title{
Inadvertent Radial Artery Avulsion during Coronary Artery Angiography
}

\author{
Chinmaya Nanda ${ }^{1}$ Vinit Garg ${ }^{1}$ Yatin Mehta ${ }^{1}$ \\ ${ }^{1}$ Medanta Institute of Critical Care and Anaesthesiology, Medanta
The Medicity, Gurgaon, India
}

J Card Crit Care:2020;4:161-162

A 53-year-old man was admitted to the hospital with complaints of dyspnea on exertion (grade 3). His resting echo showed no left ventricular regional wall motion abnormalities, with an ejection fraction of 55\%, normal right ventricular function, and mild tricuspid regurgitation. His treadmill test was mildly positive. In view of a strong family history of coronary artery disease, he was planned for a coronary angiography.

The patient underwent coronary angiography, which was performed through right radial artery catheterization using a 5-Fr Tiger catheter. Coronary angiogram showed noncritical coronary artery disease. After the angiography was over, there was resistance on pulling out the catheter and guidewire. On excessive manipulation to take out the guidewire and catheter, the catheter was sheared and the guidewire could not be taken out. After sometime, the right hand became cold and the pulse was absent distal to the puncture site. Vascular surgery consultation was taken and the patient was planned for emergency surgical exploration to remove the retained radial artery catheter ( - Fig. 1). Tip of the 5-Fr catheter was found to be outside the lumen of the radial artery in the subcutaneous plane. The radial artery was stripped ( - Fig. 2 ) and ligated at the distal end. Ulnar artery
Address for correspondence Chinmaya Nanda, MD, FIACTA, Medanta Institute of Critical Care and Anaesthesiology, Medanta The Medicity, Sector 38, Gurgaon, 122001, India (e-mail: nandachinu@gmail.com).

ultrasonography showed triphasic blood flow. The surgical wound was closed after achieving adequate hemostasis. The patient was discharged from the hospital after 3 days on medical management and follow-up advice.

The radial artery is being increasingly used for interventional procedures worldwide because of lower incidence of access site bleeding and early mobilization of the patient, leading to decreased morbidity and lesser hospital stay. Radial artery catheterization can lead to complications such as local site bleeding, forearm hematoma, fistula formation, pseudoaneurysm, radial artery occlusion, vasospasm, and sterile abscess. Radial artery avulsion due to intense vasospasm has been described, though it is rare. Ischemic injury or damage to the hand is rare in patients with prolonged cannulation of the radial artery in critically ill patients, though the radial artery may get occluded. This is because of the dual blood supply of the hand by the radial and ulnar arteries and the palmar arch. ${ }^{1-3}$ Bedford concluded that percutaneous cannulation of the radial artery for 1 to 10 days has generally been free of serious complications, although arterial occlusion may occur in 10 to $30 \%$ cases. $^{4}$

Vasospasm generally occurs in the tortuous segments and more so if there is excessive manipulation. published online

November 3, 2020
DOI https://doi.org/ 10.1055/s-0040-1718987 ISSN 2457-0206.
(C) 2020. Official Publication of The Simulation Society (TSS), accredited by International Society of Cardiovascular Ultrasound (ISCU).

This is an open access article published by Thieme under the terms of the Creative Commons Attribution-NonDerivative-NonCommercial-License, permitting copying and reproduction so long as the original work is given appropriate credit. Contents may not be used for commercial purposes, or adapted, remixed, transformed or built upon. (https:// creativecommons.org/licenses/by-nc-nd/4.0/)

Thieme Medical and Scientific Publishers Pvt. Ltd., A-12, 2nd Floor, Sector 2, Noida-201301 UP, India 


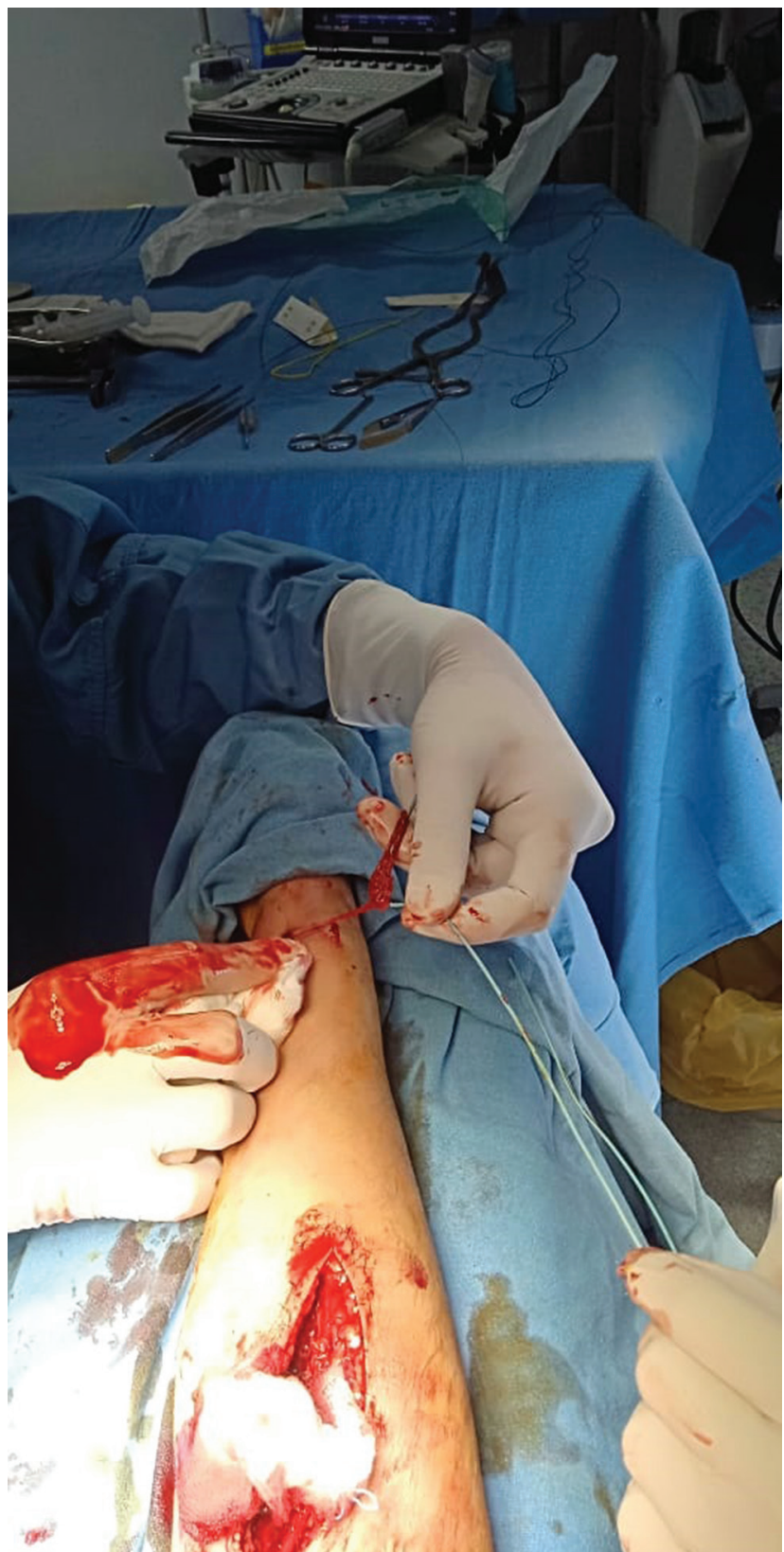

Fig. 1 Right radial artery exploration distally found congregation of radial artery and subcutaneous tissue around catheter

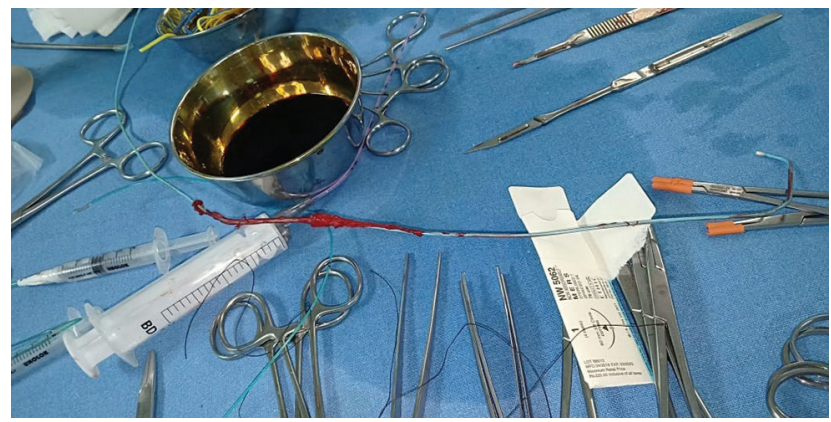

Fig. 2 Avulsed radial artery over the 5-Fr.

Excessive manipulation or use of force can lead to vasospasm, which can cause radial artery avulsion, as it happened in our case.

\section{Conflict of Interest}

None declared.

\section{References}

1 Kieffer RW, Dean RH. Complications of intra-arterial monitoring. Probl Gen Surg 1985;2:116-120

2 Kiemeneij F, Laarman GJ, Odekerken D. Slagboom T, van der Wieken R. A randomized comparison of percutaneous transluminal coronary angioplasty by the radial, brachial and femoral approaches: the access study. J Am Coll Cardiol 1997;29(6):1269-1275

3 Slogoff S, Keats AS, Arlund C. On the safety of radial artery cannulation. Anesthesiology 1983;59(1):42-47

4 Bedford RF. Long-term radial artery cannulation: effects on subsequent vessel function. Crit Care Med 1978;6(1):64-67 